\title{
Impact of the changing area sown to winter wheat on crop water footprint in the North China Plain
}

\author{
Xue Wang a,b , Xiubin $\operatorname{Li}^{\mathrm{a}, *}$, Günther Fischer ${ }^{\mathrm{c}}$, Laixiang Sun ${ }^{\mathrm{c}}$, Minghong Tan ${ }^{\mathrm{a}}$, \\ Liangjie Xin ${ }^{\mathrm{a}}$, Zhuoran Liang ${ }^{\mathrm{d}}$ \\ a Key Laboratory of Land Surface Pattern and Simulation, Institute of Geographic Sciences and Natural Resources Research, \\ Chinese Academy of Sciences, Beijing 100101, China \\ ${ }^{\mathrm{b}}$ University of Chinese Academy of Sciences, Beijing 100049, China \\ ${ }^{\mathrm{c}}$ International Institute for Applied Systems Analysis (IIASA), Schlossplatz 1, 2361 Laxenburg, Austria \\ d Shanghai Climate Center, Shanghai 200030, China
}

\section{A R T I C L E I N F O}

\section{Article history:}

Received 19 June 2014

Received in revised form 17 April 2015

Accepted 20 April 2015

\section{Keywords:}

Agricultural land use change

Groundwater intensity

Water footprint

Water scarcity

Winter wheat

\begin{abstract}
A B S T R A C T
The serious water scarcity and groundwater over-exploitation problems of the North China Plain (NCP) have aroused worldwide concerns. Achieving a reduction in agricultural water use is critical, because agriculture is the largest water consumer in the NCP. New solutions to these problems may lie in changes in the area sown to winter wheat across the NCP. In this study, the water footprint (WF) was applied as an aggregative indicator to evaluate the impact of the changing area sown to winter wheat. A Chinese version of the AEZ model, the China-AEZ model, was used for the evaluation. The results showed: (1) Green water plays a more significant role in winter wheat production in the southern part of the NCP than in the north; about a half of the water requirements for winter wheat are met by green water in the southern part of the NCP, compared to only a third in the north. (2) As a result of the north-south shift in the area sown to winter wheat during the period 1998-2011, the $W F$, the green water footprint $\left(W F_{\text {green }}\right)$ and the surface water footprint $\left(W F_{\text {blue }}^{s}\right)$ for winter wheat increased, respectively, by $459 \times 10^{6} \mathrm{~m}^{3} \mathrm{yr}^{-1}$ (0.9\%), by $973 \times 10^{6} \mathrm{~m}^{3} \mathrm{yr}^{-1}(4.2 \%)$ and by $47 \times 10^{6} \mathrm{~m}^{3} \mathrm{yr}^{-1}(0.5 \%)$, whereas the groundwater footprint $\left(W F_{\text {blue }}^{g}\right.$ ) diminished by $561 \times 10^{6} \mathrm{~m}^{3} \mathrm{yr}^{-1}$ (3.4\%). The contribution of green water also increased, from $46.3 \%$ in 1998 to $47.8 \%$ in 2011 , concurrent with the changes in the area sown to winter wheat. (3) The Hebei Plain, in the northern part of the NCP, conserved $1856 \times 10^{6} \mathrm{~m}^{3} \mathrm{yr}^{-1}$ of blue water footprint $\left(W F_{\text {blue }}\right)$ for winter wheat during the period 1998-2011, equivalent to about one third of the total amount of water supplied by the Middle Route of the South-to-North Water Transfer Project (MRP) in 2010. By comparison, WF and its components all increased in the southern provinces of the NCP. The diminishing requirement for groundwater and the increasing role of green water in winter wheat production encourage policies aimed at the further optimization of agricultural land use and the achievement of integrated blue-green water management in the NCP.
\end{abstract}

(C) 2015 Elsevier Ltd. All rights reserved.

\section{Introduction}

Water has always been regarded as a fundamental natural resource (Falkenmark, 2008; Vörösmarty et al., 2010), by providing drinking water, sanitation and a safe and abundant food supply, and through ensuring biodiversity and the functioning of pivotal ecosystems (Koehler, 2008; Huang et al., 2012). Yet water scarcity has become a worldwide issue and the associated over-exploitation

\footnotetext{
* Corresponding author. Tel.: +86 01064889297.

E-mail addresses: wangx.12b@igsnrr.ac.cn (X. Wang), lixb@igsnrr.ac.cn (X. Li).
}

of water resources has caused negative environmental impacts, notably water quality deterioration, ecosystem degradation, land subsidence and seawater ingress, over wide areas of the Middle East, southern and central Asia, North China and North America (Gleick, 2003; Fang et al., 2010; Gleeson et al., 2012). Globally, agriculture is the largest consumer of water, accounting for about 92\% of overall water use (Hoekstra and Mekonnen, 2012). To sustain increased food production, global water withdrawals have almost doubled during the past 40 years (Gleick, 2003), and water resources worldwide have been heavily exploited for agriculture (Konar et al., 2011). It is expected that water use for food production will continue to increase in the future, as a result of population 
growth and changes in dietary preferences (Rosegrant and Ringler, 2000). This will put additional pressure on global water resources. The scale of the problem is such that it is now imperative to find ways to reduce agricultural water use without affecting food supplies (Molden, 2007).

In response to global concerns about water resources, the concept of the water footprint (WF) was introduced by Hoekstra (2003), as a metric to assess water use in the production of important commodities (Hoekstra, 2003; Hoekstra and Chapagain, 2006; Hoekstra et al., 2011; Page et al., 2011). The WF of a product is defined as the volume of freshwater used to make the product, measured over the full supply chain (Hoekstra et al., 2011). It shows water consumption volumes by source (green and blue WFs) and polluted volumes by type of pollution (gray WF) (Hoekstra et al., 2011). It can therefore be regarded as a comprehensive indicator for studying the water situation from the consumption perspective (Hoekstra and Chapagain, 2006). Previous WF assessments have simulated the WF values for various crop products, for example cereals (Mekonnen and Hoekstra, 2010; Chapagain and Hoekstra, 2011; Farell et al., 2011; Bocchiola et al., 2013), vegetables (Chapagain and Orr, 2009), sweeteners and bio-ethanol (Gerbens-Leenes and Hoekstra, 2012), cotton and grape products (Chapagain et al., 2006; Herath et al., 2013). The results have indicated that three major cereal crops wheat, maize and rice - require significant amounts of water, and that $45 \%$ of the global blue water footprint is accounted for the production of wheat and rice (Mekonnen and Hoekstra, 2011).

Crop WF studies focused mainly on the quantification of green and blue water use (Zhuo et al., 2014; Zoumides et al., 2014). Green water is the infiltrated rainfall held in the unsaturated soil zone (Rockström et al., 2007). It rarely has competitive users, whereas blue water has several, e.g., industry and households. The opportunity cost of green water is low, compared with that of blue water (Liu et al., 2009). Thus, the use of green water instead of blue water places less pressure on local water supply systems. The green water proportion of consumptive water use (GWP), proposed by Liu et al. (2009), can be used to reflect the role of green water in crop production. Blue water refers to fresh water in rivers, lakes, wetlands and aquifers, and can be categorized as groundwater and surface water (Vanham et al., 2013). It is necessary to distinguish groundwater in the blue water component, since groundwater plays a central role in irrigated agriculture (Gleick, 2003; Gleeson et al., 2012). However, this lies beyond the scope of most crop WF studies (Zoumides et al., 2013; Starr and Levison, 2014).

The North China Plain (NCP) was selected as the study area. It is one of the major food production areas in China, providing about $75 \%$ of China's wheat and 35\% of its maize (Meng et al., 2012). The NCP is also amongst the global "hotspots" in terms of water scarcity (Chen et al., 2003; Gleeson et al., 2012). The agricultural sector accounts for more than $70 \%$ of total water use in the NCP, and groundwater has been the lifeblood of agriculture since the 1970s (Liu and Wei, 1989; Hu et al., 2010; Cao et al., 2013). However, in recent years, the over-exploitation of groundwater in the NCP has had devastating consequences, with potential global implications. A decrease of $10 \mathrm{~m}$ in groundwater table was recorded across the NCP within 10 years (World Bank, 2005). Problems are more serious in the northern part of the NCP, in which there is less natural precipitation; the groundwater table at the Luancheng Agricultural Ecosystem Experiment Station has decreased by more than $20 \mathrm{~m}$ within about 30 years (Chen et al., 2003; Hu and Cheng, 2011), and the groundwater depression cones in Beijing, Shijiazhuang and Cangzhou continue to expand (Jiang and Zhang, 2004; Sun et al., 2011). Of the agricultural crops in the NCP, winter wheat plays a key role in the development of severe water scarcity and in the over-exploitation of groundwater, because more than $70 \%$ of irrigation water (blue water) is consumed by winter wheat ( $\mathrm{Li}$ et al., 2005, 2008; Sun et al., 2010). Recent studies have found large, spatially continuous areas in the northern part of the NCP in which winter wheat and summer maize are being replaced by spring crops; this has been termed "the spring corn planting belt phenomenon" (Feng et al., 2007; Huang et al., 2012; Wang et al., 2014). According to statistical data (National Bureau of Statistics of China, 2012), adverse changes have occurred simultaneously in other parts of the NCP. Because winter wheat is a major water consumer, the spatial changes in the area sown to winter wheat must have had an impact on its WF across the NCP. But to what extent has the impact occurred? The resolution of this problem may provide suggestions for the alleviation of water stress in the $\mathrm{NCP}$, and hence the issue deserves in-depth analysis.

The main aims of this study were: (1) to quantify the WF changes for winter wheat under the scenario of changing winter wheat sown areas across the NCP; (2) to specify the spatial heterogeneities of the changes in green and blue WFs for winter wheat; and (3) to indicate the changes in the contributions of green and blue water to wheat production in the NCP. The China-AEZ (Chinese edition of Agro-Ecological Zones) model was applied to calculate the WF of winter wheat. The study introduces a groundwater intensity index (GI) to subdivide the blue WF into two parts, i.e., the groundwater footprint and the surface water footprint, while the GWP was estimated to assess changes in the contributions of green and blue water. Through this study, we propose to unravel the relationship between crop WF and agricultural land use change, and to give support to the development and implementation of policies on agricultural land use and water management, with the overall aims of alleviating water stress and ensuring the sustainable production of winter wheat in the NCP.

\section{Materials and methods}

\subsection{Study area}

The NCP $\left(32^{\circ} 19^{\prime} \mathrm{N}-40^{\circ} 18^{\prime} \mathrm{N} 112^{\circ} 18^{\prime} \mathrm{E}-120^{\circ} 25^{\prime} \mathrm{E}\right)$ lies in northeastern China and includes 360 counties in Beijing, Tianjin, Hebei, Henan, Shandong, Jiangsu and Anhui (Fig. 1), with a total area of $4.4 \times 10^{5} \mathrm{~km}^{2}$. It has a temperate monsoon climate, with an annual average temperature of $13^{\circ} \mathrm{C}$, and an annual average precipitation of $710 \mathrm{~mm}$. The annual precipitation occurs mainly between late June and September, while during the winter and spring months, when winter wheat has its greatest requirement for water, receive only a fifth of the annual total. There is also a south-north gradient of precipitation across the NCP during the growth season of winter wheat (Fig. 1). The fertile fluvial soil has a deep profile and a loamy texture suitable for arable farming. Winter wheat is usually sown in the middle of October and harvested in the following June.

\subsection{Data preparation}

The spatial and temporal resolutions of the datasets used in this study are listed in Table 1.

The statistical area data for winter wheat (1986-2011), at the province level and at the county level, respectively, were derived from the National Agricultural Scientific Data Sharing Center (AgriData) (Chinese Academy of Agricultural Sciences, 2012). These data were used to specify the temporal and spatial variations in the areas sown to winter wheat. The area data at the county level were also used to quantify the $W F$ for winter wheat across the NCP.

Meteorological data for the period 1981-2010, including daily and monthly maximum and minimum temperatures, precipitation, wind speed, sunshine duration, and minimum relative humidity, were obtained from the China Meteorological Data Sharing Service System (China Meteorological Administration, 2012), and were interpolated to the whole of the NCP using the thin plate smoothing splines method (Hancock and Hutchinson, 2006). 


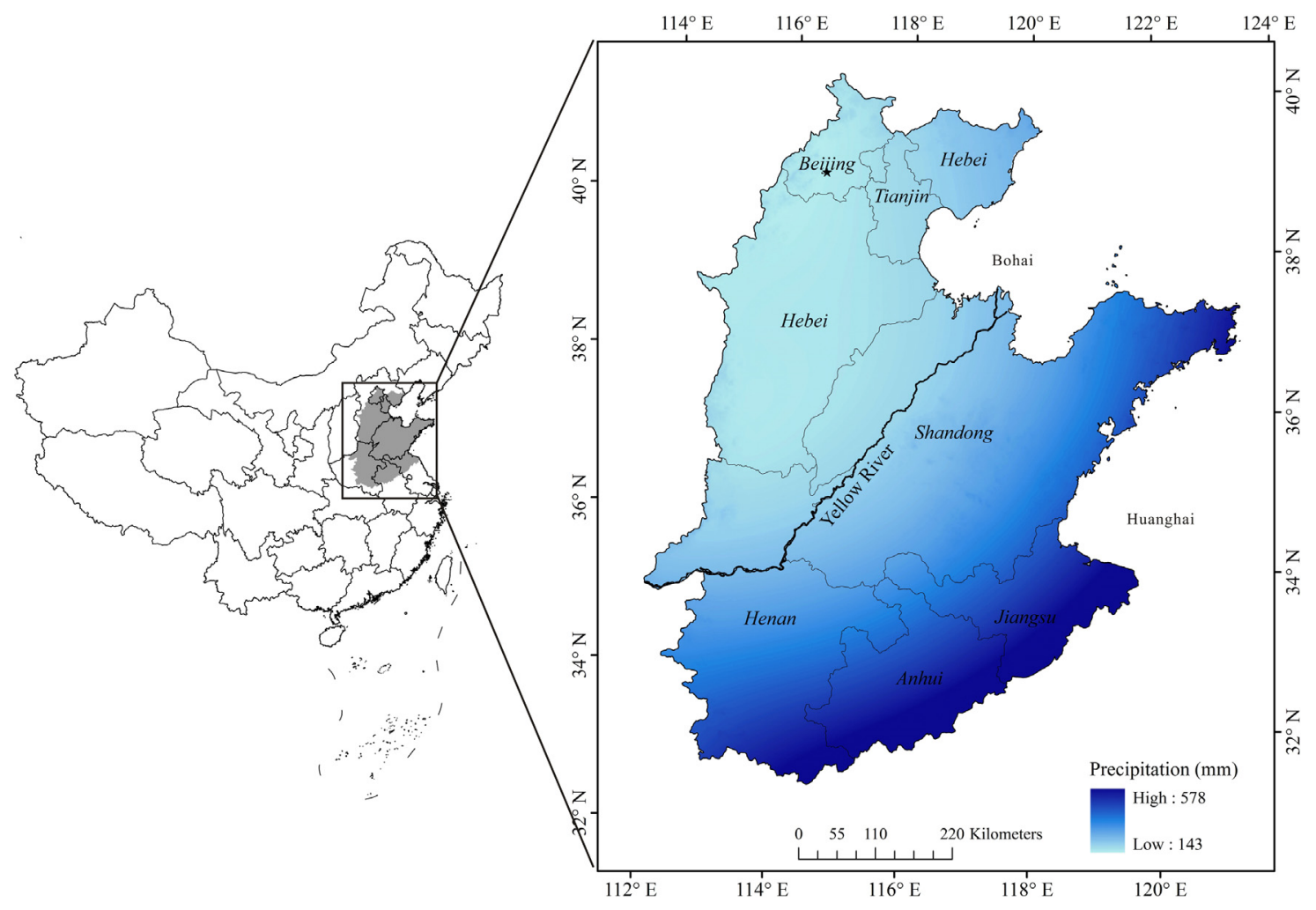

Fig. 1. Location of the North China Plain, and precipitation during the growth season of winter wheat.

Soil data, including those for soil properties and soil distributions in 2000, were obtained from the Institute of Soil Science, Chinese Academy of Sciences, with a resolution of 30 arc seconds (IIASA/FAO, 2012).

The Digital Elevation Model (DEM) data, with a resolution of 30 arc seconds, were obtained through resampling the DEM data (3 arc seconds) from the Shuttle Radar Topography Mission (SRTM) database (CGIAR-CSI, 2006). Other topographic data, for example slope and aspect data, were compiled using the DEM data.

Meteorological data, soil data and topographic data were the main inputs for the China-AEZ model. It was assumed that crops are only harvested in the grid cells where cultivated land exists; the cultivated land map was obtained from the GLC 2000 products (JRC, 2006).

Data for the rain-fed and irrigated area sown to winter wheat, with a resolution of 5 arc minutes (about $9.2 \mathrm{~km}$ at the

Table 1

Datasets used in this study.

\begin{tabular}{|c|c|c|}
\hline Datasets & Spatial reference & Source \\
\hline $\begin{array}{l}\text { 1. Statistical winter wheat } \\
\text { sown area }\end{array}$ & Province \& county & $\begin{array}{l}\text { Chinese Academy of } \\
\text { Agricultural Sciences } \\
\text { (2012) }\end{array}$ \\
\hline 2. Meteorological data & 79 stations & $\begin{array}{l}\text { China Meteorological } \\
\text { Administration (2012) }\end{array}$ \\
\hline 3. Soil data & 30 arc seconds & IIASA/FAO (2012) \\
\hline $\begin{array}{l}\text { 4. Digital elevation model } \\
\text { (DEM) }\end{array}$ & 3 arc seconds & CGIAR-CSI (2006) \\
\hline 5. Cultivated land map & 30 arc seconds & JRC (2006) \\
\hline $\begin{array}{l}\text { 6. Rain-fed area sown to } \\
\text { wheat }\end{array}$ & 5 arc minutes & Portmann et al. (2010) \\
\hline $\begin{array}{l}\text { 7. Irrigated area sown to } \\
\text { wheat }\end{array}$ & 5 arc minutes & Portmann et al. (2010) \\
\hline $\begin{array}{l}\text { 8. Statistical water and } \\
\text { groundwater withdrawal }\end{array}$ & Municipality & $\begin{array}{l}\text { National Bureau of } \\
\text { Statistics of China (2012); } \\
\text { Ministry of Water } \\
\text { Resources of China (2012) }\end{array}$ \\
\hline
\end{tabular}

equator), were obtained from the global data set of monthly irrigated and rain-fed crop areas around the year 2000 (MIRCA 2000 data) (Portmann et al., 2010). They were used to translate the gridded data for winter wheat water evapotranspiration - the results of the China-AEZ model - to the individual county level. In addition, for winter wheat, the harvested area was the sum of the rain-fed area and the irrigated area in each grid cell. Then, the proportion of rain-fed area for winter wheat $\left(P_{r}\right)$, at the county level, was calculated by dividing the total rain-fed area by the total harvested area for all the grid cells in each county. $P_{r}$ was a principal parameter for the quantification of the WF for winter wheat across the NCP. For this study, we assumed that $P_{r}$ remained the same in each county during the period 1998-2011.

The statistical data for water and groundwater withdrawal, at the municipal level, were obtained from the relevant statistical yearbooks and water resources bulletins for the year 2011 (Ministry of Water Resources of China, 2012; National Bureau of Statistics of China, 2012), and were used to calculate the groundwater intensity index $(G I)$.

\subsection{Water footprint for winter wheat}

In this study, the $W F$ for winter wheat refers to the total volume of water consumed by winter wheat in terms of evapotranspiration $(E T)$. We did not estimate the water incorporated into the harvested crop because it typically accounts for only $0.1 \%$ of the evaporated water, or up to $1 \%$ at most (Hoekstra et al., 2011). Owing to the lack of data on pollutant discharges in the NCP, we estimated only green $W F\left(W F_{\text {green }}\right)$ and blue $W F\left(W F_{\text {blue }}\right)$ for winter wheat. According to Mekonnen and Hoekstra (2010), both the $W F_{\text {green }}$ and the $W F_{\text {blue }}$ in each county can be calculated as the area-weighted average of $E T$ under rain-fed and irrigation systems, respectively. The total $W F$ $\left(W F_{\text {total }}\right)$ is the sum of $W F_{\text {green }}$ and $W F_{\text {blue }}$.

$W F_{\text {total }}=W F_{\text {green }}+W F_{\text {blue }}$ 
$W F_{\text {green }}=10 \times\left(E T_{\text {green }}^{r} \times A^{r}+E T_{\text {green }}^{i} \times A^{i}\right)$

$W F_{\text {blue }}=10 \times E T_{\text {blue }}^{i} \times A^{i}$

where $W F_{\text {total }}$ is the total $W F$ for winter wheat in one county $\left(\mathrm{m}^{3} \mathrm{yr}^{-1}\right), E T_{\text {green }}$ and $E T_{\text {blue }}$ are the green and blue water evapotranspiration $\left(\mathrm{mm} \mathrm{yr}^{-1}\right)$, originating from precipitation and irrigation, respectively, in one county during the winter wheat growth season. The superscripts $r$ and $i$ refer to rain-fed and irrigation systems, respectively. $A$ is the area sown to winter wheat in 1998 or in 2011 (ha); $A^{r}$ was calculated by multiplying $A$ by $P_{r}$ (see Section 2.2), and $A^{i}$ is the difference between $A$ and $A^{r}$. The constant 10 is used to convert $\mathrm{mm}$ into $\mathrm{m}^{3} \mathrm{ha}^{-1}$.

In this study, the annual average $E T_{\text {green }}^{r}, E T_{\text {green }}^{i}$, and $E T_{\text {blue }}^{i}$ during the period 1981-2010 were used to calculate the WF for winter wheat, offsetting the influences of extreme weather incidents. In this context, the WF changes for winter wheat across the NCP would be imposed only by agricultural land use changes.

\subsection{China-AEZ modeling methodology: crop evapotranspiration}

In this study, we used the Chinese edition of the Agro-Ecological Zones (China-AEZ) model, which was developed during the major NSFC-IIASA cooperation project: Assessing the impact of climate change and incentive human activities on China's agro-ecosystem and its supply potentials (2010-2012). The China-AEZ model takes climate, soil, and topography conditions into consideration, and simulates crop growth and water balance processes occurring throughout the soil-plant-atmosphere continuum (IIASA/FAO, 2012); it can be used to obtain the evapotranspiration (ET), including $E T_{\text {green }}$ and $E T_{\text {blue }}$, of a variety of crops. The main parameters of the China-AEZ model have been previously calibrated (Tian et al., 2011, 2012).

The ET values for rain-fed and irrigated winter wheat, respectively, were estimated, using the China-AEZ model. For rain-fed winter wheat, the only water source is rainfall (green water); $E T_{\text {green }}^{r}$ equals actual crop evapotranspiration $\left(E T_{a}\right)$ and can be calculated as:

$E T_{\text {green }}^{r}=E T_{a}=\left\{\begin{array}{cc}E T_{m} & \rho=1 \\ P+\rho \times E T_{m} & \rho<1\end{array}\right.$

where $P$ is daily precipitation. In this model, daily precipitation is assumed to be available to plants immediately, prior to the replenishment of soil moisture. The factor $\rho$ is related to the current water balance $(W b)$ and the threshold of readily available soil water $(W r)$ (IIASA/FAO, 2012): $\rho=1$ if $W b \geq W r ; 0<\rho<1$, if $W b$ is smaller than $W r$ and larger than the permanent wilting capacity; $\rho=0$, if $W b$ is smaller than the permanent wilting capacity.

For an irrigation system, the China-AEZ model allows optimal timing of irrigation and assumes no water deficit for winter wheat (IIASA/FAO, 2012). Therefore, actual crop evapotranspiration $\left(E T_{a}\right)$ equals maximum crop evapotranspiration $\left(E T_{m}\right)$, including the use of both blue water and green water during the crop growth season (IIASA/FAO, 2012). $E T_{m}$ is the product of the reference evapotranspiration and the crop coefficient:

$E T_{m}=\sum_{i=1}^{N} k c_{i} \times E T_{o_{i}}$

where $k c$ is the crop coefficient, which varies during the crop growth season. The $k c$ values for winter wheat were obtained from Allen (1998). $N$ is the length of the normal growth season. In this study, we assumed that winter wheat with a growth season of 140 days was cultivated across the NCP; the starting date could be determined automatically by the model, provided that the daily mean temperature exceeded $5{ }^{\circ} \mathrm{C}$. $E T_{o}$, the reference crop evapotranspiration, was estimated using the widely applied Penman-Monteith equation (Allen et al., 1998).

The $E T_{\text {green }}^{i}$ for winter wheat can also be calculated using Eq. (4), and the $E T_{\text {blue }}^{i}$ for winter wheat, i.e., irrigation, was calculated as:

$E T_{\text {blue }}^{i}=E T_{m}-E T_{\text {green }}^{i}$

In this study, a resolution of 30 arc seconds was taken for simulation in the China-AEZ model; and the resolution of the output files was the same. They were transferred to maps with a resolution of 5 arc minutes. Then, maps for the rain-fed and irrigated areas sown to winter wheat around the year 2000 were taken into consideration, in order to obtain the annual average values for $E T_{\text {green }}^{r}, E T_{\text {green }}^{i}$, and $E T_{\text {blue }}^{i}$ in each county. Taking $E T_{\text {green }}^{r}$ as an example,

$E T_{\text {green }}^{r}=\sum_{j=1}^{n}\left(E T_{\text {green }, j}^{r} \times C U L_{j}^{r}\right) / \sum_{j=1}^{n} C U L_{j}^{r}$

where $E T_{\text {green }, j}^{r}$ is the annual average green water evapotranspiration of pixel $j$ in one county during 1981-2010 $\left(\mathrm{mm} \mathrm{yr}^{-1}\right)$, under the rain-fed system; $C U L_{j}^{r}$ is the rain-fed area sown to winter wheat in pixel $j ; j=1,2, \ldots, n$. The annual average $E T_{\text {green }}^{i}$ and $E T_{\text {blue }}^{i}$ in each county can be aggregated in the same way, using the map for the irrigated area sown to winter wheat around 2000.

\subsection{Green water proportion of water footprint}

According to Liu et al. (2009), the green water proportion (GWP, $\%)$ is calculated as the ratio of green water footprint $\left(W F_{\text {green }}\right)$ to total water footprint $\left(W F_{\text {total }}\right)$. In this study, the GWP of winter wheat in each county was assumed to remain constant during the period 1998-2011, and was calculated using Eq. (8). The rain-fed and irrigation systems were both taken into consideration:

$G W P=\frac{\left[E T_{\text {green }}^{r} \times P_{r}+E T_{\text {green }}^{i} \times\left(1-P_{r}\right)\right]}{\left[E T_{\text {green }}^{r} \times P_{r}+\left(E T_{\text {green }}^{i}+E T_{\text {blue }}^{i}\right) \times\left(1-P_{r}\right)\right]}$

For the NCP as a whole, the GWP of winter wheat was estimated as the ratio of total green water footprint to the total water footprint of winter wheat:

$G W P_{n c p}=\sum_{k=1}^{360} W F_{\text {green }}^{k} / \sum_{k=1}^{360} W F_{\text {total }}^{k}$

where $G W P_{n c p}$ is the green water proportion in the NCP in 1998 or in 2011. $W F_{\text {green }}^{k}$ and $W F_{\text {total }}^{k}$ are total green water footprint and total water footprint in county $k$, respectively, in 1998 or in 2011, and $k=1,2, \ldots, 360$.

\subsection{Groundwater intensity index}

In this study, the concept of groundwater intensity index (GI) is proposed, to separate groundwater and surface water from the $W F_{\text {blue }}$ of winter wheat in the NCP (Fig. 2).

$G I=G / T$

$G I$ (as \%) is calculated as the ratio of groundwater withdrawal $\left(G, \mathrm{~m}^{3} \mathrm{yr}^{-1}\right)$ to total water withdrawal $\left(T, \mathrm{~m}^{3} \mathrm{yr}^{-1}\right)$ within a region. It has been assumed to be homogeneous for all counties within all municipalities of the NCP (Fig. 3). As agriculture accounts for more than $70 \%$ of total water withdrawal in the NCP (Sun et al., 2010), GI can be regarded roughly as representative of agricultural groundwater intensity, which is the ratio of the groundwater footprint $\left(W F_{\text {blue }}^{g}\right)$ to the overall $W F_{\text {blue }}$. We assumed that the ratios of $W F_{\text {blue }}^{g}$ to $W F_{\text {blue }}$ were similar amongst different agricultural production sectors. Therefore, the higher the value of GI, the larger the proportion of $W F_{\text {blue }}^{g}$ in the $W F_{\text {blue }}$ for winter wheat, and the greater the pressure exerted on groundwater resources. The $W F_{\text {blue }}^{g}\left(\mathrm{~m}^{3} \mathrm{yr}^{-1}\right)$ 


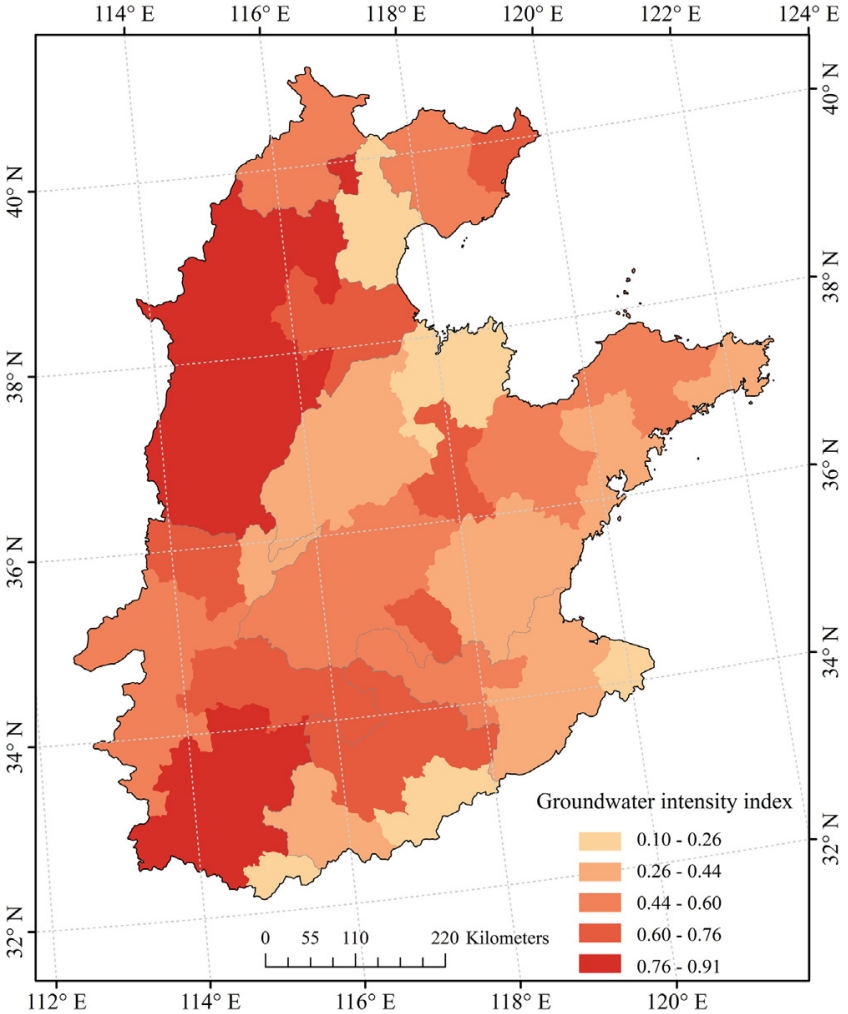

Fig. 2. Spatial distribution of groundwater intensity index (GI) across the NCP.

and the surface water footprint $\left(W F_{b l u e}^{s}, \mathrm{~m}^{3} \mathrm{yr}^{-1}\right)$ for winter wheat can be calculated as:

$W F_{\text {blue }}^{g}=G I \times W F_{\text {blue }}$

$W F_{\text {blue }}^{s}=W F_{\text {blue }}-W F_{\text {blue }}^{g}$

\section{Temporal and spatial variations in the areas sown to winter wheat}

There were few changes in the areas sown to winter wheat in all seven cities/provinces during the period 1986-1997, whereas the pattern of change was different after 1998 (Fig. 3). The areas sown to winter wheat in Henan and in Anhui steadily increased during the

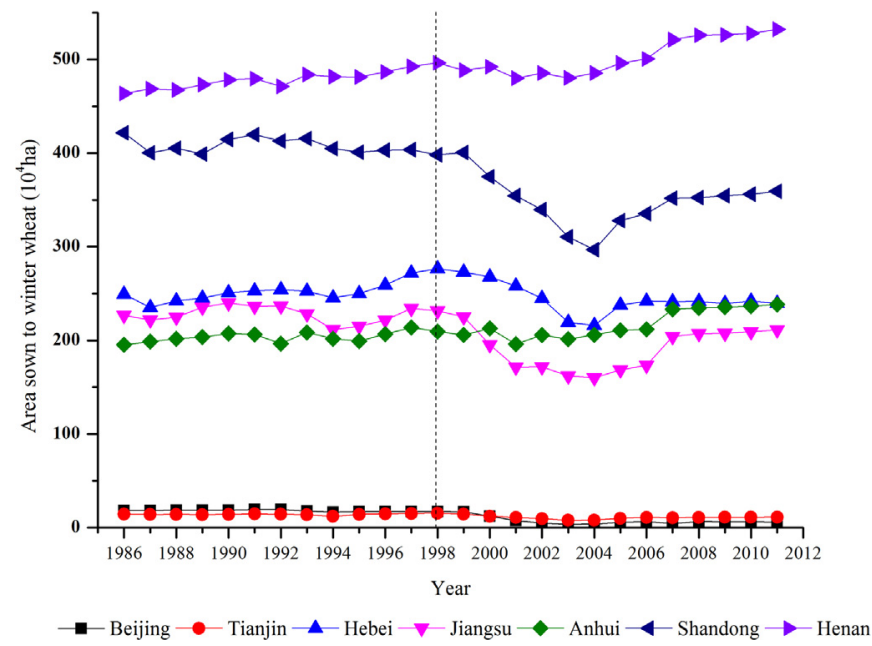

Fig. 3. Changes in areas sown to winter wheat in seven cities/provinces during 1986-2011.
Table 2

Statistical analysis of sown areas and production figures for winter wheat at the county level.

\begin{tabular}{lccccr}
\hline & \multicolumn{2}{c}{ Sown area $\left(10^{4} \mathrm{ha}\right)$} & & \multicolumn{2}{c}{ Production $\left(10^{4} \mathrm{t}\right)$} \\
\cline { 2 - 3 } \cline { 5 - 6 } & 1998 & 2011 & & 1998 & 2011 \\
\hline Maximum & 16.13 & 12.87 & & 94.44 & 88.79 \\
Minimum & 0.00 & 0.00 & & 0.01 & 0.00 \\
Average & 3.64 & 3.76 & & 17.10 & 25.41 \\
Median & 1.64 & 1.43 & & 1.71 & 1.32 \\
Total & 1312 & 1352 & & 6157 & 9147 \\
\hline
\end{tabular}

period 1998-2011. In comparison, in the other five cities/provinces, the areas sown initially decreased, during the period 1998-2004, and then increased again after 2004. The areas sown in 2011 in the five cities/provinces were still smaller than in 1998.

The total area sown to winter wheat in the NCP was $1352 \times 10^{4}$ ha in 2011 , which was $40 \times 10^{4}$ ha (3.0\%) more than in 1998 (Table 2). There were large spatial differences between different regions of the NCP in the changes of the areas sown to winter wheat (Fig. 4). Increases were mainly found in counties in northeastern and southeastern Shandong, in the plain areas of Henan, and in northern Anhui and northern Jiangsu, which are located primarily in the southern part of the $\mathrm{NCP}\left(<36^{\circ} \mathrm{N}\right)$; while reductions roughly focused on the counties in the north of the $\mathrm{NCP}\left(>36^{\circ} \mathrm{N}\right)$. The Hebei Plain, which includes all the plain counties of Beijing, Tianjin and Hebei (Wang et al., 2013), showed the largest reductions in the areas sown to winter wheat, which decreased overall by $17.1 \%$ during the period $1998-2011$.

In conclusion, the area sown to winter wheat had shifted to the southern NCP counties $\left(<36^{\circ} \mathrm{N}\right)$ during the period $1998-2011$, after a long stable period lasting from 1986 to 1997 . This phenomenon would have resulted in temporal and spatial changes for the WF of

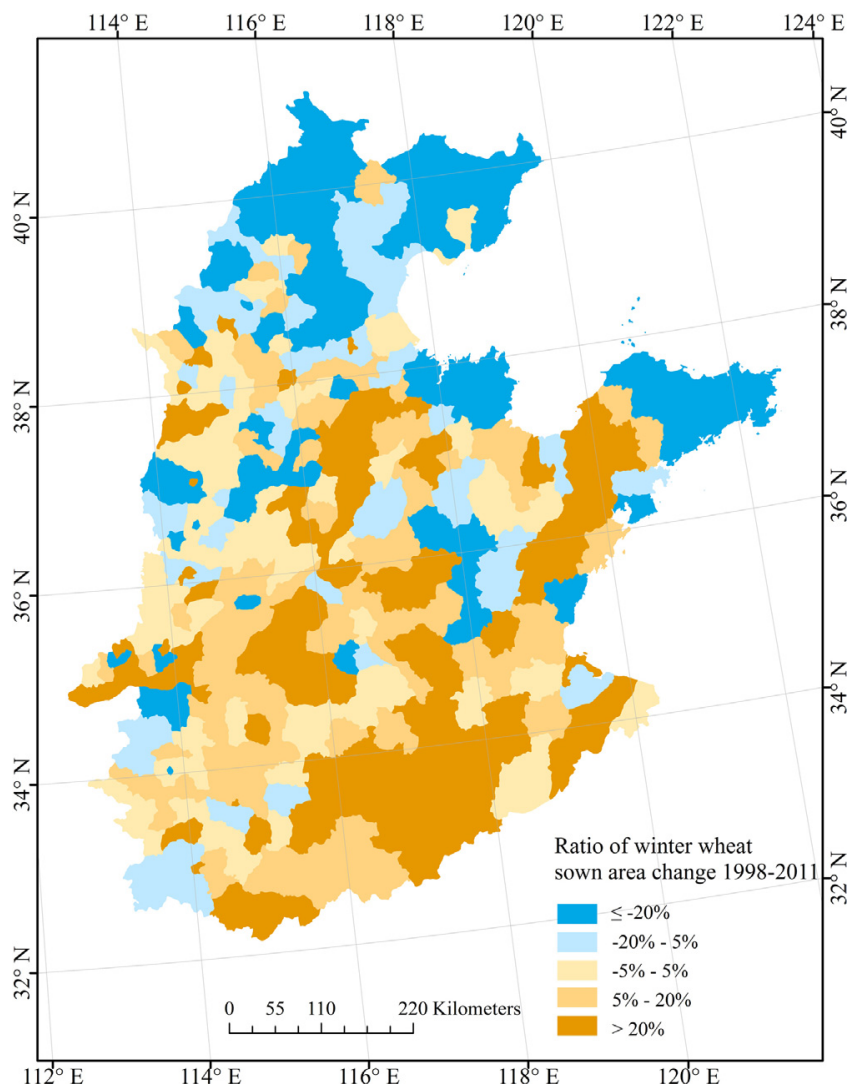

Fig. 4. Spatial distribution of the changes (\%) in the areas sown to winter wheat between 1998 and 2011. 
winter wheat in the NCP, which are considered in detail in Section 5 . In addition, winter wheat production in the NCP increased by $2990 \times 10^{4}$ t over the period 1998-2011 (Table 2), concurrent with the north-south shift of the area sown to winter wheat.

\section{Spatial variations in the green water proportion of winter wheat}

As previously mentioned, GWP is an indicator reflecting the role of green water in winter wheat production. Considering the low opportunity cost of green water, the larger the GWP, the more green water and the less blue water will be used, and therefore less pressure will be exerted on local water supply systems and their surrounding environment.

Analysis of spatial variations in the GWP for winter wheat (Fig. 5) showed that the values for GWP decreased from the southeast to the north of the NCP. Green water played a significant role in the southern part of the $\mathrm{NCP}\left(<36^{\circ} \mathrm{N}\right)$, where values for GWP were larger than $50 \%$; green water predominated the production of winter wheat in counties south of $34^{\circ} \mathrm{N}$, where values for GWP were larger than $80 \%$. In comparison, it was blue water, rather than green water, that made prominent contributions to winter wheat production in the northern part $\left(>36^{\circ} \mathrm{N}\right)$, where values for GWP were less than $33 \%$. Therefore, less pressure was exerted on local water supply systems and the environment for winter wheat production in the southern part of the NCP than in the north.

For the NCP as a whole, the GWP for winter wheat would have changed on account of the north-south shift of the areas sown to winter wheat during the period 1998-2011. But to what extent had the change actually occurred? The answer will also be presented in Section 5 .

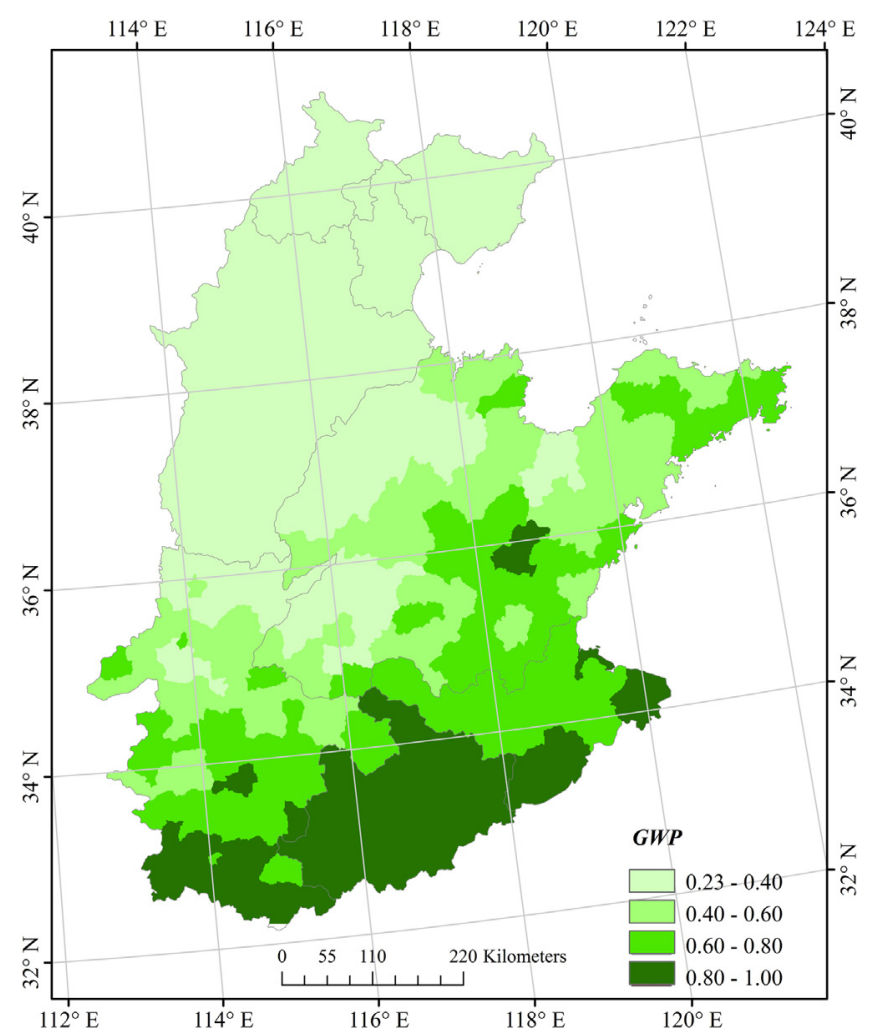

Fig. 5. Green water proportion (GWP, \%) for winter wheat at the county level (average for the period 1981-2010).

\section{Quantification of the changes in water footprint for winter wheat}

In this section, we have quantified the $W F$ changes for winter wheat across the NCP during the period 1998-2011, for which a north-south shift of the area sown to winter wheat was identified, without considering the effects of extreme weather incidents. The spatial distributions of the changes are shown in Fig. 6.

\subsection{WF changes for winter wheat in the NCP, and spatial variations}

The $W F_{\text {total }}$ increased by $459 \times 10^{6} \mathrm{~m}^{3} \mathrm{yr}^{-1}(0.9 \%)$ between 1998 and 2011 across the NCP as a whole, implying that a little more water was required for winter wheat production in this region in 2011 than in 1998 . The spatial distribution of the changes in $W F_{\text {total }}$ was similar to that shown in Fig. 3, i.e., to the spatial distribution of the changes in area sown to winter wheat. Thus, increases in $W F_{\text {total }}$ occurred mostly in the southern part of the $\mathrm{NCP}\left(<36^{\circ} \mathrm{N}\right)$, and also in the counties of northwestern Shandong and in Weifang (a city in eastern Shandong); by contrast, decreases in $W F_{\text {total }}$ occurred mainly in the north of the $\mathrm{NCP}\left(>36^{\circ} \mathrm{N}\right)$, including the counties located in the Hebei Plain, the eastern Shandong Peninsula and the Yellow River mouth area (Fig. 6a).

The $W F_{\text {green }}$ for winter wheat increased by $973 \times 10^{6} \mathrm{~m}^{3} \mathrm{yr}^{-1}$ (4.2\%) between 1998 and 2011 in the NCP, which was a larger increase than that for $W F_{\text {total }}$. Large increases in $W F_{\text {green }}$ occurred mainly in the counties in southwestern Shandong and to the south of $34^{\circ} \mathrm{N}$ (Fig. 6b), with expansions in the area sown to winter wheat and high values for GWP (Figs. 4 and 5). There were also obvious decreases in $W F_{\text {green }}$ in counties located in the eastern Shandong Peninsula, and around $40^{\circ} \mathrm{N}$.

In contrast to the increases in $W F_{\text {total }}$ and $W F_{\text {green }}$ in the NCP, there was a decrease in $W F_{\text {blue }}$, amounting to $514 \times 10^{6} \mathrm{~m}^{3} \mathrm{yr}^{-1}$ (1.9\%), between 1998 and 2011. For the two components of $W F_{\text {blue }}$, the value of $W F_{\text {blue }}^{g}$ decreased by $561 \times 10^{6} \mathrm{~m}^{3} \mathrm{yr}^{-1}(3.4 \%)$, and decreases of $W F_{\text {blue }}^{g}$ were mainly found in counties of the Hebei Plain (Fig. 6d), owing to the severe shrinkages of the area sown to winter wheat (Fig. 4). In addition, the value for $W F_{\text {blue }}^{s}$ was $47 \times 10^{6} \mathrm{~m}^{3} \mathrm{yr}^{-1}$ $(0.5 \%)$ greater in 2011 than in 1998 , implying that the changes in the contribution of surface water to winter wheat production were minimal across the NCP.

For the NCP as a whole, the GWP for winter wheat increased from $46.3 \%$ in 1998 to $47.8 \%$ in 2011 , revealing that green water had made a greater contribution to winter wheat production, concomitant with the southward shift of winter wheat sown areas across the NCP. Thus, in terms of water provision, winter wheat production was less blue water dependent in the NCP in 2011 than in 1998.

\subsection{WF changes for winter wheat at the province level}

At the province level (Table 3), it is clear that the NCP can be separated into two parts, i.e., the northern part, also referred to as the Hebei Plain, including Beijing, Tianjin and Hebei, with a severe shrinkage in area sown to winter wheat and a decrease in $W F_{\text {total }}$ (of $2606 \times 10^{6} \mathrm{~m}^{3} \mathrm{yr}^{-1}$ ) for winter wheat production, and the southern part, including Shandong, Henan, Jiangsu and Anhui, where the $W F_{\text {total }}$ for winter wheat increased by $3065 \times 10^{6} \mathrm{~m}^{3} \mathrm{yr}^{-1}$ during the period 1998-2011.

In the Hebei Plain, the decrease in $W F_{\text {blue }}$ for winter wheat amounted to $1856 \times 10^{6} \mathrm{~m}^{3} \mathrm{yr}^{-1}$, equivalent to $32.6 \%$ of the total volume of water supplied to Beijing, Tianjin and Hebei in 2010 by the Middle Route of the South-to-North Water Transfer Project (MRP) (Table 4), which aims to divert water from the middle reaches of the Changjiang River, to meet the developing 

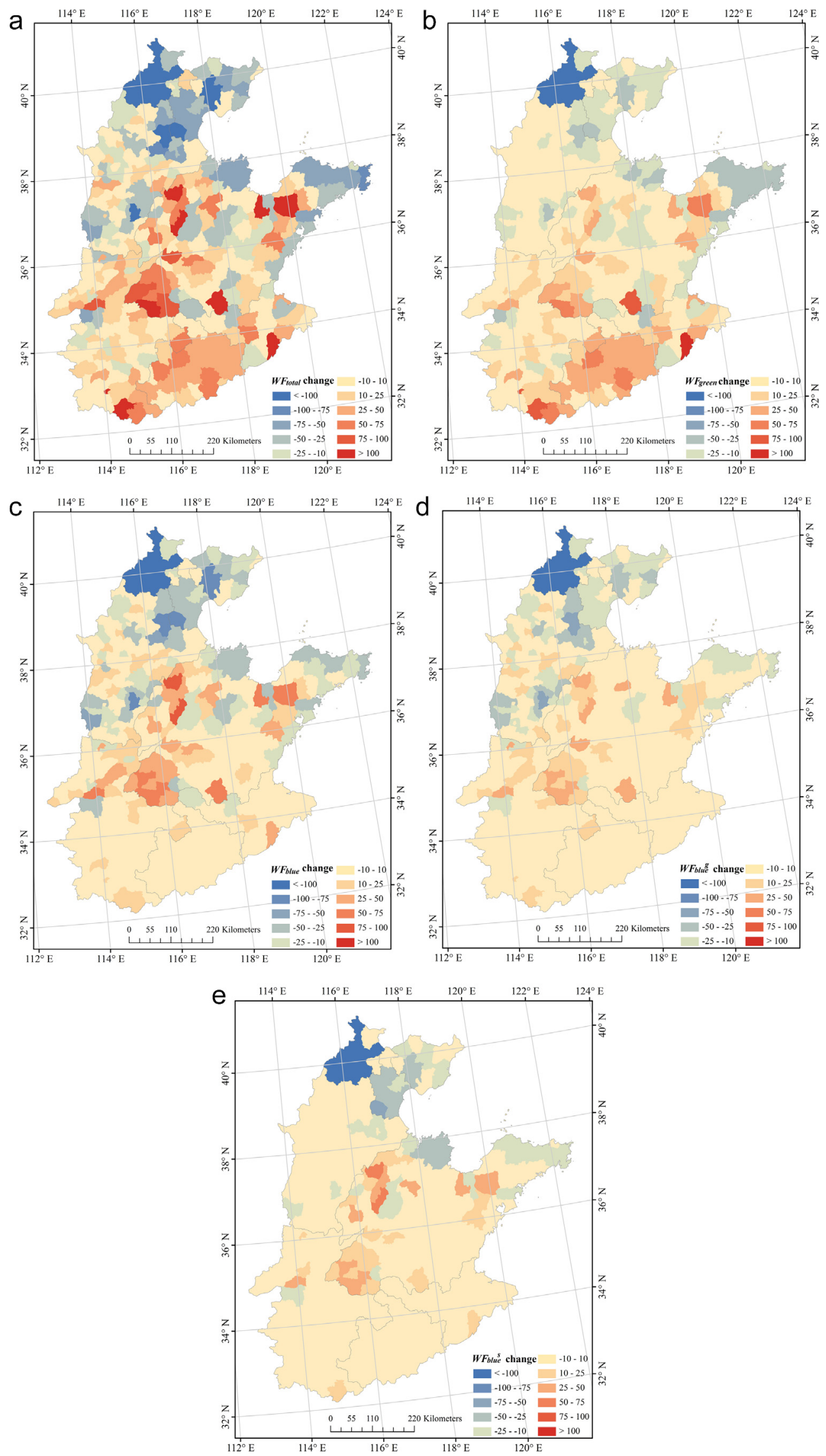

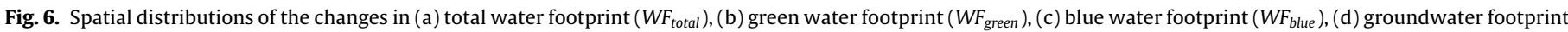
$\left(\left(W F_{\text {blue }}^{g}\right)\right)$ and (e) surface water footprint $\left(W F_{\text {blue }}^{s}\right)$ for winter wheat during the period 1998-2011; all values are in $10^{6} \mathrm{~m}^{3} \mathrm{yr}^{-1}$. 
Table 3

Changes in water footprint for winter wheat at the province level between 1998 and 2011.

\begin{tabular}{|c|c|c|c|c|c|c|}
\hline \multirow[t]{2}{*}{ Region } & \multicolumn{6}{|l|}{ WF change } \\
\hline & Value $\left(10^{6} \mathrm{~m}^{3} \mathrm{yr}^{-1}\right)$ & $\%$ Change & $W F_{\text {green }}$ change $\left(10^{6} \mathrm{~m}^{3} \mathrm{yr}^{-1}\right)$ & $W F_{\text {blue }}$ change $\left(10^{6} \mathrm{~m}^{3} \mathrm{yr}^{-1}\right)$ & $\begin{array}{l}W F_{\text {blue }}^{g} \text { change } \\
\left(10^{6} \mathrm{~m}^{3} \mathrm{yr}^{-1}\right)\end{array}$ & $\begin{array}{l}W F_{\text {blue }}^{s} \text { change } \\
\left(10^{6} \mathrm{~m}^{3} \mathrm{yr}^{-1}\right)\end{array}$ \\
\hline Beijing & -546 & -65.7 & -162 & -384 & -231 & -153 \\
\hline Tianjin & -199 & -26.2 & -55 & -144 & -37 & -106 \\
\hline Hebei & -1861 & -13.5 & -532 & -1329 & -1026 & -303 \\
\hline Shandong & 1095 & 6.9 & 280 & 816 & 421 & 395 \\
\hline Henan & 1053 & 8.4 & 627 & 425 & 275 & 150 \\
\hline Jiangsu & 210 & 8.1 & 189 & 21 & -1 & 21 \\
\hline Anhui & 707 & 18.5 & 626 & 81 & 39 & 43 \\
\hline Total & 459 & 0.9 & 973 & -514 & -561 & 47 \\
\hline
\end{tabular}

Table 4

Agricultural water consumption and water supplied by the Middle Route of the South-to-North Water Transfer Project (MRP) in the Hebei Plain in 2010 (unit: $10^{6} \mathrm{~m}^{3} \mathrm{yr}^{-1}$ ).

\begin{tabular}{lll}
\hline & Agricultural water consumption & Water supplied by the MRP \\
\hline Beijing & 1080 & 1200 \\
Tianjin & 1100 & 1000 \\
Hebei & - & 3500 \\
Hebei Plain & - & 5700 \\
\hline
\end{tabular}

requirements of northwestern and northern China (Changjiang Water Resources Commission of the Ministry of Water Resources, 2003). In this context, a substantial volume of blue water has been released in the Hebei Plain, and less pressure has been exerted on local water resources, in terms of winter wheat production.

However, the reduction in $W F_{\text {blue }}^{g}$ of winter wheat in the Hebei Plain was $15 \%$ during the period 1998-2011; this is less than the threshold of $29.2 \%$ in the reduction of local irrigation water required to stop groundwater drawdown and less than the threshold of $39.2 \%$ required to induce groundwater recovery and restoration, as proposed by Hu et al. (2010) through their research in the Shijiazhuang Irrigation District. Therefore, much more should be done in the Hebei Plain to reverse the over-exploitation of groundwater resources. It is worth mentioning that the reduction in $W F_{\text {blue }}$ in Beijing amounted to about $65.7 \%$, which is larger than the second threshold of $39.2 \%$ referred to previously, and may be the main cause of the reduction in groundwater drawdown in Beijing in 2012 (Beijing Water-affair Authority, 2012). From the perspective of agricultural land use adjustment across the NCP, this therefore raises an important prospect for the mitigation of groundwater problems through the further reduction of $W F_{\text {blue }}^{g}$.

In the southern NCP provinces, the $W F_{\text {green }}$ and $W F_{\text {blue }}$ for winter wheat increased overall by $1722 \times 10^{6} \mathrm{~m}^{3} \mathrm{yr}^{-1}(9.0 \%)$ and $1343 \times 10^{6} \mathrm{~m}^{3} \mathrm{yr}^{-1}$ (8.6\%), respectively, accounting for $56.2 \%$ and $43.8 \%$, respectively, of the increase in $W F_{\text {total }}\left(3065 \times 10^{6} \mathrm{~m}^{3} \mathrm{yr}^{-1}\right)$; the value of GWP also increased from $54.2 \%$ to $54.9 \%$. Therefore, more green water had contributed to the production of winter wheat in the southern part of the NCP between 1998 and 2011, which was in accordance with changes in the contribution of green water in the NCP as a whole. In addition, there was still a large percentage (about $65.9 \%$ ) of $W F_{\text {blue }}$ originating from groundwater in Henan, as indicated by high GI values. In this context, it is vital to find ways to reduce groundwater use for winter wheat production even in the southern NCP provinces.

\section{Discussion and conclusion}

This study has made a major effort to quantify explicitly the impact of the north-south shift of the area sown to winter wheat on its green, blue, ground and surface water footprint (WF) in the NCP. The results show that the spatial changes in the area sown to winter wheat led to decreases in the use of blue water and groundwater, and increases in the use of green water and surface water, in 2011 as compared to 1998 . The rise in the green water proportion (GWP), from $46.3 \%$ to $47.8 \%$, confirmed the increasing importance of green water in winter wheat production across the NCP. The contribution of groundwater diminished, and spatial analysis showed that a large decrease in the groundwater footprint $\left(W F_{\text {blue }}^{g}\right)$ for winter wheat occurred mainly in the Hebei Plain, with a severe shrinkage in the area sown to winter wheat and high GI values.

This study has revealed that large savings $\left(561 \times 10^{6} \mathrm{~m}^{3} \mathrm{yr}^{-1}\right)$ were made in the amount of groundwater used for winter wheat production and that this water was therefore available for other uses. It sheds light on possibilities for economization in the use of irrigation groundwater from the perspective of agricultural land use change. From our point of view, policies on agricultural land use optimization should be encouraged, with the aim of relieving the pressure on groundwater resources for crop production in the NCP. Since irrigation groundwater is mostly restricted to winter wheat as maize grows during the rainy season, reducing the area sown to winter wheat and enhancing the planting of a single crop of maize could be a possible option to economize on groundwater use, especially in the Hebei Plain, where groundwater problems are most severe (Xu et al., 2005; Shen et al., 2013). This is also consistent with the regime named "land rehabilitation", under discussion by the central government, which aims to alleviate water stress and relieve groundwater over-exploitation in the NCP (State Council of China, 2014). However, any change of this kind would be counter-productive and would cause a decrease in local food self-sufficiency. To achieve the trade-offs between alleviating water resource over-exploitation and food self-sufficiency, the import of food from regions with abundant water resources and a greater adoption of water-efficient production systems would appear to be the best solutions (Yang and Zehnder, 2007; Huang et al., 2012).

According to our study, green and blue water are both essential for winter wheat production in the NCP. However, previous water policies focused mainly on the management of blue water (Huang et al., 2012; State Council of China, 2012), whereas green water management was often marginalized by water resource planners (Savenije, 2000). Taking into account the increasing role of green water in winter wheat production across the NCP and the gap between the reduction ratio of $W F_{\text {blue }}^{g}(15.0 \%)$ and the threshold of $39.2 \%$ to induce groundwater recovery and restoration in the Hebei Plain, there is an urgent need to adopt integrated water management. Previously ignored green water management strategies should be formulated, and these should be combined with the improvement of blue water management. Measures for green water utilization, for example rainwater harvesting and biotechnological advances (Liu et al., 2009), should be emphasized, especially in the southern provinces of the NCP, where the role of green water is more important for winter wheat production. Close attention should also be paid to blue water resources, especially groundwater; boosting the price of agricultural irrigation water, the use of 
brackish water, and sprinkle irrigation are all possible strategies to reverse groundwater over-exploitation and to promote groundwater storage (Yang et al., 2000; Cao et al., 2013).

Finally, we would like to acknowledge the main shortcomings of this study. Firstly, because the largest agricultural water consumer in the NCP is winter wheat (Li et al., 2005), for simplicity we only investigated the impact of changes in the area sown to winter wheat on the WF; we did not investigate concurrent changes in $W F$ for other crops in the NCP. More work needs to be done to quantify the changes in WF for other crops that have occurred concurrently with the north-south shift of the area sown to winter wheat, to provide a more accurate assessment of the limitation and expansion of crop WF values across the NCP. Secondly, the groundwater intensity index (GI), an innovative parameter introduced in this study, is an important indicator in the assessment of changes in $W F_{\text {blue }}^{g}$ change for winter wheat. However, the calculation of GI was approximate, owing to a lack of data. Further work to achieve an accurate separation of the groundwater footprint from $W F_{\text {blue }}$ is still needed, for the purpose of revealing explicitly the pressure of crop production on groundwater resources. Thirdly, this study focused on the quantification of changes in the $W F$ for winter wheat as impacted by a scenario of changes in agricultural land use, without considering the influences of climatic variability, which also exert major effects on crop water footprint (Sun et al., 2010; Bocchiola et al., 2013; Yang et al., 2013). Taking precipitation as an example, previous researchers have noted that the NCP has undergone a declining trend in precipitation since the 1960s, which has resulted in incremental increases in blue water consumption for crop production (Hu et al., 2002; Sun et al., 2010). In terms of precipitation forecasting, some researchers have predicted a maximum reduction of $4 \mathrm{~mm}$ in mean annual precipitation by the year 2030 for this region (Gao et al., 2002; Wang et al., 2012). If precipitation continues to decline in the future, and is accompanied by changes in other meteorological parameters, such as temperature, wind speed and humidity, to what extent will these climatic developments affect the $W F$ for crop production? Will they threaten food security in the NCP? These questions deserve in-depth analysis, because the answers obtained will provide valuable information for water resource planning and future decision-making.

In conclusion, accurate quantification of the impact of agricultural land use change on crop WF values still remains a challenging task, on account of important shortcomings in the availability of data and the complexity of agricultural activities and climate variability in water-scarce areas. Nonetheless, this study has quantified explicitly the impact of the north-south shift in the area sown to winter wheat upon the WF for this crop within the NCP during the period 1998-2011, and has uncovered a potential for alleviating water availability problems from the perspectives of agricultural land use optimization and integrated water management.

\section{Acknowledgments}

This work was supported by the NSFC-IIASA Young Scientists Summer Program (YSSP) (Y22X0301AE) and the NSFC-IIASA International Cooperation and Exchange Program (41161140352). We thank Harrij van Velthuizen (IIASA) for his contributions during the research. We also thank Guiying Cao, Bill Cosgrove, David Wiedberg, and Paul Yillia from IIASA, for their valuable comments and suggestions. Last but not least, we thank the editors and two anonymous reviewers for their critical and constructive comments on earlier versions of the manuscript.

\section{References}

Allen, R.G., Pereira, L.S., Raes, D., Smith, M., 1998. Crop evapotranspiration: guidelines for computing crop water requirements, FAO Irrigation and Drainage Paper No 56. FAO-Food and Agriculture Organization Press, Rome.
Beijing Water-affair Authority, 2012. Beijing Water Resources Bulletin, Available at: http://www.bjwater.gov.cn/pub/bjwater/index.html

Bocchiola, D., Nana, E., Soncini, A., 2013. Impact of climate change scenarios on crop yield and water footprint of maize in the Po valley of Italy. Agric. Water Manag. $116,50-61$

Cao, G., Zheng, C., Scanlon, B.R., Liu, J., Li, W., 2013. Use of flow modeling to assess sustainability of groundwater resources in the North China Plain. Water Resour. Res. 49, http://dx.doi.org/10.1029/2012wr011899

CGIAR-CSI, 2006. NASA Shuttle Radar Topographic Mission (SRTM), Available at: http://srtm.csi.cgiar.org/

Changjiang Water Resources Commission of the Ministry of Water Resources, 2003. An introduction to the planning of the Middle Route of the South-to-North Water Diversion Project (revised version in 2011). China Water Resour. 1, 48-51 (in Chinese).

Chapagain, A.K., Hoekstra, A.Y., 2011. The blue, green and grey water footprint of rice from production and consumption perspectives. Ecol. Econ. 70, 749-758.

Chapagain, A.K., Hoekstra, A.Y., Savenije, H.H.G., Gautam, R., 2006. The water footprint of cotton consumption: an assessment of the impact of worldwide consumption of cotton products on the water resources in the cotton producing countries. Ecol. Econ. 60, 186-203.

Chapagain, A.K., Orr, S., 2009. An improved water footprint methodology linking global consumption to local water resources: a case of Spanish tomatoes. J. Environ. Manag. 90, 1219-1228.

Chen, J.Y., Tang, C.Y., Shen, Y.J., Sakura, Y., Kondoh, A., Shimada, J., 2003. Use of water balance calculation and tritium to examine the dropdown of groundwater table in the piedmont of the North China Plain (NCP). Environ. Geol. 44 564-571.

China Meteorological Administration, 2012. China Meteorological Data Sharing Service System, Available at: http://cdc.cma.gov.cn/

Chinese Academy of Agricultural Sciences, 2012. National Agricultural Scientific Data Sharing Center (AgriData), Available at: http://www.agridata.cn/

Falkenmark, M., 2008. Water and sustainability: a reappraisal. Environ.: Sci. Policy Sustain. Dev. 50, 4-17.

Fang, Q.X., Ma, L., Green, T.R., Yu, Q., Wang, T.D., Ahuja, L.R., 2010. Water resources and water use efficiency in the North China Plain: current status and agronomic management options. Agric. Water Manag. 97, 1102-1116.

Farell, C., Turpin, S., Suppen, N., 2011. Assessment of the water footprint of wheat in Mexico. In: Finkbeiner, M. (Ed.), Towards Life Cycle Sustainability Management. pp. 161-170.

Feng, Z.M., Liu, D.W., Zhang, Y.H., 2007. Water requirements and irrigation scheduling of spring maize using GIS and CropWat model in Beijing-Tianjin-Hebei region. Chin. Geogr. Sci. 17, 56-63.

Gao, Q., Xu, Y., Ren, Z., 2002. Trend analysis of precipitation of arid areas in China. Eng. Sci. 4, 36-43.

Gerbens-Leenes, W., Hoekstra, A.Y., 2012. The water footprint of sweeteners and bio-ethanol. Environ. Int 40, 202-211.

Gleeson, T., Wada, Y., Bierkens, M.F.P., van Beek, L.P.H., 2012. Water balance of globa aquifers revealed by groundwater footprint. Nature 488, 197-200.

Gleick, P.H., 2003. Global freshwater resources: soft-path solutions for the 21st century. Science 302, 1524-1528.

Hancock, P.A., Hutchinson, M.F., 2006. Spatial interpolation of large climate data sets using bivariate thin plate smoothing splines. Environ. Model. Softw. 21, 1684-1694.

Herath, I., Green, S., Singh, R., Horne, D., van der Zijpp, S., Clothier, B., 2013. Water footprinting of agricultural products: a hydrological assessment for the water footprint of New Zealand's wines. J. Clean. Prod. 41, 232-243.

Hoekstra, A.Y. (Ed.), 2003. Virtual Water Trade: Proceedings of the International Expert Meeting on Virtual Water Trade. Delft, The Netherlands, 12-13 December 2002, Value of Water Research Report Series No. 12. UNESCO-IHE, Delft, The Netherlands, Available at: www.waterfootprint.org/Reports/Report12.pdf

Hoekstra, A.Y., Chapagain, A.K., 2006. Water footprints of nations: water use by people as a function of their consumption pattern. Water Resour. Manag. 21, 35-48.

Hoekstra, A.Y., Chapagain, A.K., Aldaya, M.M., Mekonnen, M.M. (Eds.), 2011. The Water Footprint Assessment Manual: Setting the Global Standard. Earth Scan, London.

Hoekstra, A.Y., Mekonnen, M.M., 2012. The water footprint of humanity. Proc. Natl. Acad. Sci. 109, 3232-3237.

Hu, C.S., Cheng, Y.S. (Eds.), 2011. National Ecosystem Positioning Observation and Research Data Set: Field Ecosystem Volume, Hebei Luancheng Station (1998-2008). China Agriculture Press, Beijin.

Hu, C.S., Zhang, X.Y., Cheng, Y.S., Pei, D., 2002. An analysis on dynamics of water table and overdraft in the piedmont of Mt Taihang. Syst. Sci. Compr. Stud. Agric. 18 89-91 (in Chinese).

Hu, Y., Moiwo, J.P., Yang, Y., Han, S., Yang, Y., 2010. Agricultural water-saving and sustainable groundwater management in Shijiazhuang Irrigation District, North China Plain. J. Hydrol. 393, 219-232.

Huang, J., Bradley, G.R., Xu, C.C., Zhang, H.L., Chen, F., 2012. Cropping pattern modifications change water resource demands in the Beijing metropolitan area. J. Integr. Agric. 11, 1914-1923.

IIASA/FAO, 2012. Global Agro-Ecological Zones (GAEZ v3.0). IIASA, Laxenburg, Austria and FAO, Rome, Italy.

Jiang, J., Zhang, Y.Q., 2004. Soil water balance and water use efficiency on irrigated farmland in the North China Plain. J. Soil Water Conserv. 18, 61-65 (in Chinese).

JRC, 2006. Global 2000 Land Cover (GLC2000), Available at: http://bioval.jrc.ec. europa.eu/products/glc2000/glc2000.php 
Koehler, A., 2008. Water use in LCA: managing the planet's freshwater resources. Int. J. Life Cycle Assess. 13, 451-455.

Konar, M., Dalin, C., Suweis, S., Hanasaki, N., Rinaldo, A., Rodriguez-Iturbe, I., 2011. Water for food: the global virtual water trade network. Water Resour. Res. 47, http://dx.doi.org/10.1029/2010WR010307

Li, H., Zheng, L., Lei, Y., Li, C., Liu, Z., Zhang, S., 2008. Estimation of water consumption and crop water productivity of winter wheat in North China Plain using remote sensing technology. Agric. Water Manag. 95, 1271-1278.

Li, J., Inanaga, S., Li, Z., Eneji, A.E., 2005. Optimizing irrigation scheduling for winter wheat in the North China Plain. Agric. Water Manag. 76, 8-23.

Liu, C.M., Wei, Z.Y. (Eds.), 1989. Agricultural Hydrology and Water Resources in the North China Plain. Chinese Scientific Press, Beijing, China.

Liu, J., Zehnder, A.J.B., Yang, H., 2009. Global consumptive water use for crop production: the importance of green water and virtual water. Water Resour. Res. 45, http://dx.doi.org/10.1029/2007WR006051

Mekonnen, M.M., Hoekstra, A.Y., 2010. A global and high-resolution assessment of the green, blue and grey water footprint of wheat. Hydrol. Earth Syst. Sci. 14, 1259-1276.

Mekonnen, M.M., Hoekstra, A.Y., 2011. The green, blue and grey water footprint of crops and derived crop products. Hydrol. Earth Syst. Sci. 15, 1577-1600.

Meng, Q., Sun, Q., Chen, X., Cui, Z., Yue, S., Zhang, F., Römheld, V., 2012. Alternative cropping systems for sustainable water and nitrogen use in the North China Plain. Agric. Ecosyst. Environ. 146, 93-102.

Ministry of Water Resources of China (Ed.), 2012. China Water Resources Bulletin (2011). China Water Power Press, Beijing, China.

Molden, D. (Ed.), 2007. Water for Food, Water for Life: A Comprehensive Assessment of Water Management in Agriculture. Earthscan, London, UK.

National Bureau of Statistics of China, 2012. National Data, Available at: http://data. stats.gov.cn/

Page, G., Ridoutt, B., Bellotti, B., 2011. Fresh tomato production for the Sydney market: an evaluation of options to reduce freshwater scarcity from agricultural water use. Agric. Water Manag. 100, 18-24.

Portmann, F.T., Siebert, S., Döll, P., 2010. MIRCA2000-global monthly irrigated and rainfed crop areas around the year 2000: a new high-resolution data set for agricultural and hydrological modeling. Glob. Biogeochem. Cycles 24, http://dx. doi.org/10.1029/2008GB003435

Rockström, J., Lannerstad, M., Falkenmark, M., 2007. Assessing the water challenge of a new green revolution in developing countries. Proc. Natl. Acad. Sci. U. S. A. 104, 6253-6260.

Rosegrant, M.W., Ringler, C., 2000. Impact on food security and rural development of transferring water out of agriculture. Water Policy 1, 567-586.

Savenije, H.H.G., 2000. Water scarcity indicators; the deception of the numbers. Phys. Chem. Earth B: Hydrol. Oceans Atmos. 25, 199-204.

Shen, Y., Zhang, Y., Scanlon, R.B., Lei, H., Yang, D., Yang, F., 2013. Energy/water budgets and productivity of the typical croplands irrigated with groundwater and surface water in the North China Plain. Agric. For. Meteorol. 181, 133-142.

Starr, G., Levison, J., 2014. Identification of crop groundwater and surface water consumption using blue and green virtual water contents at a subwatershed scale. Environ. Process. 1, 497-515.

State Council of China, 2012. National Agricultural Water-Saving Program (2012-2020), Available at: http://www.gov.cn/zwgk/2012-2012/2015/content 2291002.htm
State Council of China, 2014. Several Opinions on Comprehensively Deepen Rural Reform to Accelerate Agricultural Modernization, Available at: http://www.gov. cn/gongbao/content/2014/content_2574736.htm

Sun, H., Shen, Y., Yu, Q., Flerchinger, G.N., Zhang, Y., Liu, C., Zhang, X., 2010. Effect of precipitation change on water balance and WUE of the winter wheat-summe maize rotation in the North China Plain. Agric. Water Manage. 97, 1139-1145.

Sun, Q., Kröbel, R., Müller, T., Römheld, V., Cui, Z., Zhang, F., Chen, X., 2011. Optimization of yield and water-use of different cropping systems for sustainable groundwater use in North China Plain. Agric. Water Manag. 98, 808-814.

Tian, Z., Liang, Z.R., Shi, J., Fischer, G., Gu, T.T., 2011. Analysis of impact on China wheat potential productivity of climate change during 1961-2010. Chin. Agric. Sci. Bull. 29, 61-69.

Tian, Z., Zhong, H.L., Sun, L.X., Fischer, G., Liang, Z.R., 2012. Estimating potentia yield of wheat production in China based on cross-scale data-model fusion. In: IEEE 4th International Symposium on Plant Growth Modeling, Simulation, Visualization and Applications, pp. 388-395.

Vörösmarty, C.J., McIntyre, P.B., Gessner, M.O., Dudgeon, D., Prusevich, A., Green, P. Glidden, S., Bunn, S.E., Sullivan, C.A., Liermann, C.R., Davies, P.M., 2010. Globa threats to human water security and river biodiversity. Nature 467, 555-561.

Vanham, D., Hoekstra, A.Y., Bidoglio, G., 2013. Potential water saving through changes in European diets. Environ. Int. 61, 45-56.

Wang, C.H., Li, J., Li, X.L., Xu, X.G., 2012. Analysis of quasi-periodic characteristics of precipitation in recent 50 years and trend in next 20 years in China. Arid Zone Res. 29, 1-10 (in Chinese).

Wang, X., Li, X., Xin, L., 2014. Impact of the shrinking winter wheat sown area on agricultural water consumption in the Hebei Plain. J. Geogr. Sci. 24, 313-330.

Wang, X., Li, X.B., Xin, L.J., 2013. Impact of the shrinking winter wheat sowing area on agricultural water consumption in the Hebei plain. Acta Geogr. Sin. 68, 707-719.

World Bank, 2005. The World Bank's Assistance of Water Resources Management in China. World Bank Press, pp. 1.

Xu, Y., Mo, X., Cai, Y., Li, X., 2005. Analysis on groundwater table drawdown by land use and the quest for sustainable water use in the Hebei Plain in China. Agric. Water Manag. 75, 38-53.

Yang, H., Zehnder, A., 2007. Virtual water: an unfolding concept in integrated water resources management. Water Resour. Res. 43, http://dx.doi.org/10.1029/ 2007wr006048

Yang, X., Chen, F., Song, D., Gong, F., Zhu, W., 2000. Experimental study on practica agricultural water-saving measures on Huabei Plain. Prog. Geogr. 19, 162-166 (in Chinese)

Yang, X., Gao, W., Shi, Q., Chen, F., Chu, Q., 2013. Impact of climate change on the water requirement of summer maize in the Huang-Huai-Hai farming region. Agric. Water Manag. 124, 20-27.

Zhuo, L., Mekonnen, M.M., Hoekstra, A.Y., 2014. Sensitivity and uncertainty in crop water footprint accounting: a case study for the Yellow River basin. Hydrol. Earth Syst. Sci. 18, 2219-2234

Zoumides, C., Bruggeman, A., Hadjikakouc, M., Zachariadis, T., 2014. Policy-relevan indicators for semi-arid nations: the water footprint of crop production and supply utilization of Cyprus. Ecol. Indic. 43, 205-214.

Zoumides, C., Bruggeman, A., Zachariadis, T., Pashiardis, S., 2013. Quantifying the poorly known role of groundwater in agriculture: the case of Cyprus. Water Resour. Manag. 27, 2501-2514. 